\title{
SETYO NOVANTO SEBAGAI MEME INTERNET: ANALISIS DIMENSI MIMETIK DI YOUTUBE
}

\author{
Lara Sakti Nur Rohmah, Rina Sari Kusuma \\ Program Studi Ilmu Komunikasi, Universitas Muhammadiyah Surakarta \\ Email : larasakti22@gmail.com; Rinasari.Kusuma@ums.ac.id
}

\begin{abstract}
ABSTRAK
Perkembangan teknologi membuat penyebaran informasi berpindah begitu cepat. Cepatnya penyebaran informasi dari satu orang ke orang lain disebut dengan viral. Berbagai hal viral mudah ditemukan di dunia maya, misalnya gambar viral, video viral, status viral, hingga lagu viral. Sesuatu yang sedang viral di media sosial kerap dijadikan bahan meme oleh warganet. Meme menjadi fenomena hangat di dunia maya dan menjadi wahana hiburan karena sifatnya yang lucu dan menghibur. Salah satu meme yang sempat viral dan menjadi perbincangan hangat di jagat maya adalah meme kasus korupsi e-KTP Setya Novanto. Meme Setya Novanto diunggah ke Youtube oleh warganet sebagai ekspresi kesal dan marah masyarakat atas berbagai "drama" yang dilakukan Setya Novanto di kasus e-KTP. Tujuan penelitian ini adalah untuk mengetahui konstruksi pesan meme internet Setya Novanto di Youtube berdasakan model analisis tiga dimensi meme. Metode penelitian ini adalah analisis isi dengan mengikuti model analisis meme Loar Shifman, yakni dengan memecah setiap video menjadi tiga dimensi: content (konten), form (bentuk), dan stance (sudut pandang).
\end{abstract}

Kata kunci: Viral, Meme internet, Youtube, Setya Novanto

\begin{abstract}
The development of technology makes information disseminated fastly. The quick dissemination from one person to another is called viral. Many viral things can be found in social media, for example viral photos, viral videos, viral status and also viral songs. Something viral on social media is often turned into meme by netizen. Meme becomes hot phenomenon on social media and becomes an entertainment because of its funny and entertaining attributes. One of memes which was viral and became discourse in social media was meme of E-KTP corruption case which involved Setya Novanto. Meme of Setya Novanto was uploaded to Youtube by netizen as society expression of anger and upset on every drama's done in E-KTP case. The purpose of this research is to determine message construction of internet meme Setya Novanto based on three-dimentional analysis model of meme. The research method used in this reasearch is content-analysis by derivating analysis model Loar Shifman meme, by dividing video becomes three dimentions consisting of content, form, and stance.
\end{abstract}

Keywords: Viral, Internet meme, Youtube, Setya Novanto

\section{A. PENDAHULUAN}

Dierateknologi,tentumediasosialbukan menjadi hal yang asing bagi kebanyakan orang. Mediasosialmemberikankemudahan untuk berkomunikasi, menyampaikan informasi, dan mempermudah interaksi publik di berbagai belahan dunia. Berbagai kemudahan yang disediakannya membuat media sosial tidak dapat dipisahkan dari kehidupan manusia (Amin et al., 2018).

Melalui media sosial, sesuatu yang sederhana dan unik bisa tibatiba diperbincangkan banyak orang. Peristiwa seperti kesenian, budaya, politik 
hingga situasi sosial mendadak ramai diperbincangkan. Video dan foto pun mencapai tingkat popularitas tertentu di web atau media sosial. Hal ini terjadi karena adanya penyebaran informasi yang begitu cepat di internet. Cepatnya penyebaran informasi dari satu orang ke orang lain ini disebut dengan viral.

Berbagai hal yang viral mudah ditemukan di internet, misalnya gambar viral, video viral, status viral, hingga lagu viral. Sesuatu yang sedang viral di media sosial kerap dijadikan meme oleh warganet. Viral yang mampu bertahan akan berevolusi menjadi memetika, yakni unit konten yang menghasilkan turunan buatan pengguna dalam bentuk remake, parodi, atau imitasi (Shifman, 2014: 73). Foto dan video viral di Indonesia maupun mancanegara yang kemudian berubah menjadi meme diantaranya: I Feel Free Syahrini (2014), PPAP (Pen Pineapple Apple Pen) (2016), The Power of Setnov (2017), Karma's a Bitch (2018), dan lagu Abdullah (2018).

Viral merupakan proses difusi dari mulut ke mulut, dimana pesan berpindah secara cepat dari satu orang ke orang lain tanpa adanya suatu gangguan (Shifman, 2014: 73). Salah satu kejadian viral yang sempat hebohkan dunia maya yakni video Edy Rahmayadi, ketua umum Persatuan Sepak Bola Indonesia (PSSI) yang melontarkan ucapan "apa hak Anda bertanya pada saya" ketika sedang diwawancarai salah satu program berita televisi. Ucapan Edy Rahmayadi tersebut begitu viral hingga membuat warganet ramai-ramai membuat tagar \#SiapPakEdy di Twitter.

Foto atau video yang mencapai tingkat popularitas tertentu di web kemungkinan besar akan diubah dan diimitasi banyak orang. Banyak meme dimulai dari sesuatu yang viral. Foto dan video viral ini bisa menjadi meme ketika ditambahkan teks yang mengandung pesan dan sudut pandang tertentu. Pesan dari teks yang disampakan biasanya diambil dari suatu kejadian di masyarakat yang sedang hangat diperbicangkan (Ilham, 2017). Kejadian tersebut bisa berupa pekerjaan, pendidikan, cinta, politik, agama, dan lain sebagainya yang sedang populer di masyarakat. Tentu meme dan viral merupakan dua hal yang berbeda. Meme adalah fenomena yang dihasilkan secara kolektif, sementara viral merujuk pada satu video, gambar, atau teks yang dibagikan secara luas (Shifman, 2014). Video viral sering memancing pegguna internet untuk membuat remake, remix, parodi, dan konten memeika lainnya.

Meme yang menyebar di media sosial membuat siapapun bisa mengunggah ulang dan membuatnya menjadi banyak versi. Meme yang dibuat pun tidak jarang bermuatan kritik sosial. Viral, meme, dan kritik sosial merupakan suatu hal yang berkesinambungan. Meme menjadi sarana untuk menyuarakan kritik sosial terhadap isu atau fenomena yang sedang hangat diperbincangkan di media sosial. Fenomena yang menuai kritik sosial biasanya datang dari tokoh politik. Politikus menjadi sasaran empuk bagi para kreator meme. Dalam menyuarakan kritik sosial, meme tidak sekedar untuk mengkritik saja, namun juga digunakan sebagai nasihat dan pengingat bagi pembacanya.

Beberapa contoh kejadian viral yang dijadikan meme dapat dilihat pada gambargambar berikut:

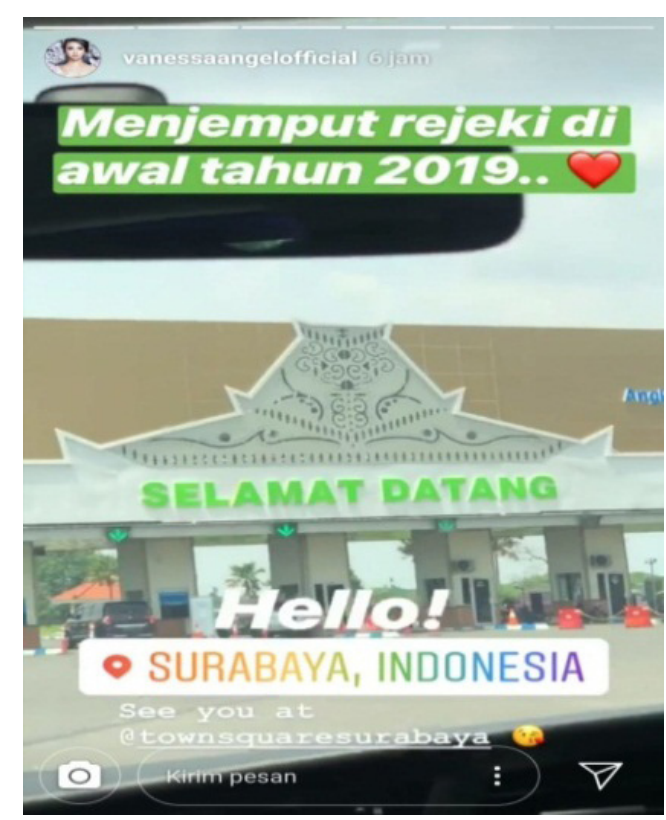

Gambar 1. Story instagram Vanessa Angel 


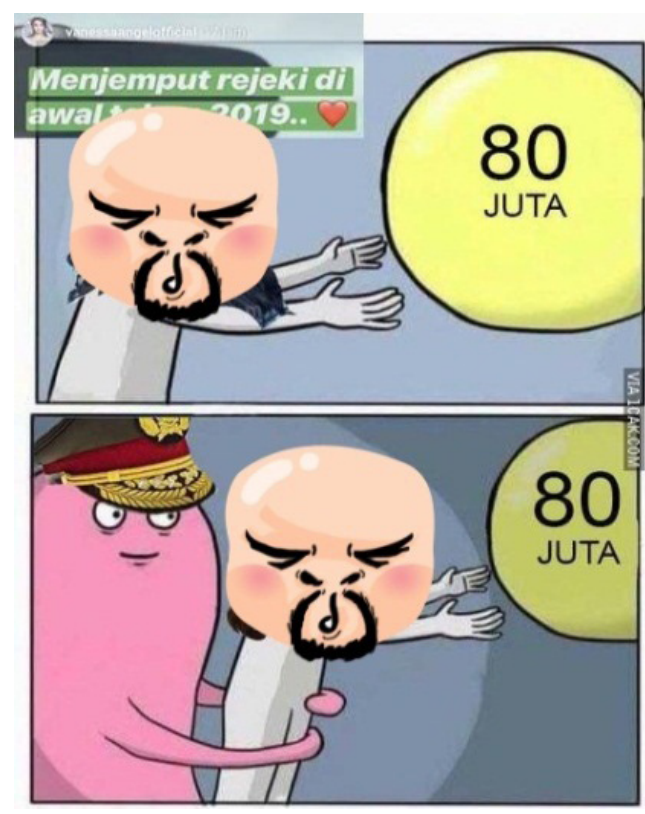

Gambar 2. Meme menjemput rejeki

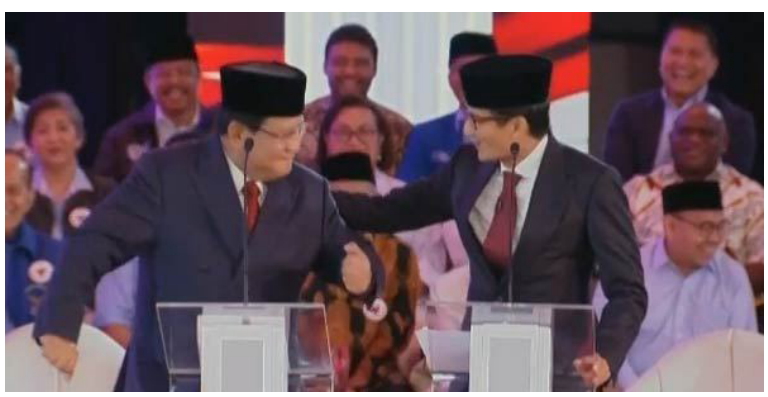

Gambar 3. Aksi joget Prabowo saat debat capres 2019

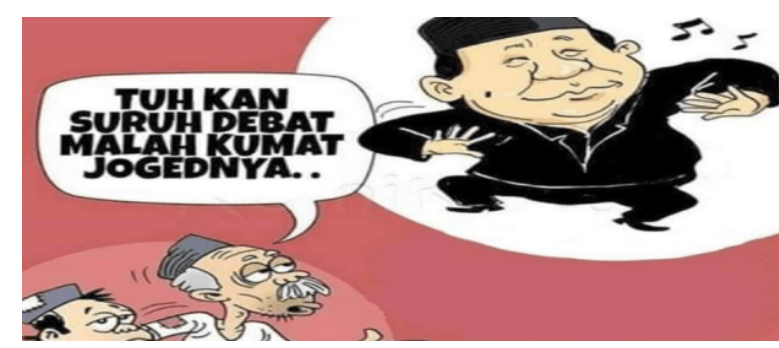

Gambar 4. Meme joget Prabowo

Istilah "meme" awal mulanya diperkenalkan oleh Richard Dawkins pada tahun 1976 dalam bukunya The Selfish Gene. Kata meme berasal dari bahasa Yunani, yakni mimesis, yang berarti tiruan. Meme dimaknai sebagai unit transmisi budaya dan dialirkan dari orang ke orang dengan cara menyalin atau meniru (Gal et al., 2015). Transmisi budaya tersebut bisa berbentuk ide, lagu, mode pakaian pemikiran, populer, cara membuat pot atau lengkungan yang dapat membentuk kebudayaan tertetu.
Meme dapat menyebar dalam bentuk aslinya, tetapi sering juga memunculkan turunan atau pembaharuan yang dibuat pengguna. Menurut $\mathrm{Xu}$ et al., (2016), di era web 2.0 pengguna dapat mengedit berbagai segmen video dan menggabungkannya kembali untuk membuat mashup video. Mereka juga dapat meniru tindakan dan gaya dalam video asli dan membuat karya turunan dalam bentuk parodi. Video turunan semacam parodi bukan merupakan penyalinan langsung dan penyampaian konten asli, tetapi suatu bentuk yang menyerupai dan berdasarkan elemen memetika yang ada (Xu et al., 2016)

Keberadaan internet yang sangat terbuka turut menjadi lahan yang subur bagi perkembangan meme. Internet dan berbagai aplikasinya menyediakan tempat yang ideal untuk distribusi meme dalam skala besar, hal ini karena meme digital dapat menyebar dengan cepat dan akurat (Heylighen, 1996 as cited in Shifman, 2012). Fleksibilitas dan aksesibilitas internet memungkinkan pengguna dengan mudah membuatmeme dan mengubahnya menjadi versi yang baru. Shifman (2012) menyebut bahwa salah satu platform yang unik untuk penyebaran meme adalah Youtube.

Youtube merupakan media sosial yang cukup digemari warganet. Youtube sendiri diciptakan oleh mantan karyawan Paypal, yakni Chad Hurley, Jawed Karim dan Steven Chen pada Februari 2005 (David et al., 2017). Menurut Budiargo (2015), Youtube merupakan video online yang digunakan untuk mencari, melihat, dan berbagi video dari segala penjuru dunia melalui suatu web. Beragam konten kreatif dan asyik membuat Youtube semakin populer di dunia maya. Beberapa konten yang cukup digemari warganet diantaranya gaming, parodi, review, tutorial, vlog, dan seputar informasi (Syahid, 2018). Sebagian besar konten Youtube dibuat oleh pengunggah amatir, namun konten ini terus berkembang dan diproduksi secara semi profesional (Soha, 2016).

Sebagai media massa, Youtube berperan aktif dalam proses transmisi 
budaya. Tampilan audio visual yang dimiliki Youtube dapat mempermudah warganet dalam memahami informasi yang ditransformasikan. Youtube secara tidak langsung dapat menyalurkan nilai-nilai dan norma tertentu melalui video atau konten yang ditampilkan. Transmisi informasi, nilai, norma, dan budaya dari Youtube dapat berpengaruh pada peniruan atau perubahan pola pikir, perilaku, ataupun cara berbusana. Salah satu bentuk transmisi budaya di Youtube yakni adanya peniruan gaya atau tindakan dari video viral yang kemudian ditiru dalam bentuk parodi.

Terdapat dua kelebihan Youtube yang membedakannya dengan media sosial lain, yakni tidak adanya batasan durasi untuk mengunggah video dan tersedianya editor sederhana, (Gal et al., 2015). Youtube memainkan peran sentral dalam 'Web 2.0' atau era 'budaya partisipatif, dimana pengguna dapat berperan sebagai produsen sekaligus distributor konten. Shifman (2012), menjelaskan bahwa Youtube berperan sebagai pusat difusi meme, hal ini yang membuat meme di Youtube begitu bervariasi dan akhirnya mencapai tingkat popularitas tertentu (viral).

Youtube secara aktif digunakan untuk kegiatan demokratis dan partisipatif. Beberapa tahun terakhir ini, Youtube juga digunakan sebagai media kritik berbagai isu sosial politik yang disampaikan melalui meme internet bernada tajam. Dalam konteks Indonesia, hal tersebut dilihat dalam hubungannya sebagai respon ekspresif masyarakat pasca orde baru.

Meme politik yang cukup terkenal di dunia maya pada tahun 2017 yakni meme The Power of Setnov. Setnov merupakan sapaan akrab dari Setya Novanto mantan ketua DPR RI 2014-2019. Setnov dikenal licin dalam setiap kasus yang menyeretnya, antara lain Cessie Bank Bali (1999), beras Vietnam (2003), limbah B3 (2006), proyek PON Riau (2012), papa minta saham (2015) dan yang terakhir adalah kasus korupsi e-KTP (2017) (Margianto, 2016).

Licinnya Setya Novanto dalam setiap kasus yang menjeratnya membuat warganet kebanjiran materi akan dirinya. Sejak kasus papa minta saham, banyak meme yang bermunculan untuk menyindir Setya Novanto yang saat itu diduga mencatut nama Joko Widodo dan Jusuf Kalla untuk meminta saham PT Freeport. Namun puncak sindiran warganet akan Setya Novanto terdapat pada kasus korupsi e-KTP. Melalui media sosial, mantan ketua DPR RI ini dijadikan bahan candaan satir melalui kreasi meme. Kasus bermula dari menangnya Setya Novanto dari gugatan praperadilan atas status tersangka dalam korupsi e-KTP, dilanjut dengan drama kecelakaan menabrak tiang listrik, hingga bungkamnya Setya Novanto dalam sidang perdananya. Setelah beberapa kejadian tersebut, di media sosial banyak bermunculan tagar \#ThePowerofSetnov, \#SaveTiangListrik, dan \#Papacepatsembuh. Tagar tersebut digunakan sebagai ekspresi kekesalan masyarakat terhadap Setya Novanto yang selalu lepas dari jeratan hukum. Beredarnya tagar, sindiran, dan kata-kata satir yang dialamatkan pada Setya Novanto juga bertujuan untuk memberikan efek malu dan kritik sosial pada kasus ini.

Jika dibandingkan dengan politikus lain di Indonesia, Setya Novanto termasuk politikus yang cukup sering dijadikan meme oleh warganet. Dirinya sering menjadi sorotan dan viral di media sosial. Setnov terkenal dengan politikus yang kebal hukum dan tidak tahu malu. Hal tersebut karena keterlibatannya dalam berbagai kasus hukum sejak 1999. Setya Novanto diduga terkait sejumlah perkara, namun tidak satu pun yang berujung di pengadilan. Kekebalan Setnov yang begitu nyata terhadap hukum membuatnya begitu memeable.

Meme terdiri dari dua aspek, yakni aspek visual dan aspek teks (Nasrullah, 2015: 126). Aspek visual biasanya menggunakan potongan gambar atau ilustrasi yang digunakan untuk menunjukkan emosi seseorang. Sedangkan aspek teks ditandai dengan adanya tulisan yang memuat pesan tertentu yang berada di antara gambar atau ilustrasi. Kemudahan teknologi dan kreativitas dari pengguna media sosial 
menandakan bahwa meme tidak sekedar ungkapan ekspresi, namun sudah menjadi ikon budaya media sosial itu sendiri.

Setiap orang bisa mengetahui meme melalui indera mereka, lalu mengolahnya dalam pikiran, dan kemudian mereka mengemas ulang untuk diteruskan kepada orang lain (Shifman, 2013: 19). Dalam proses ini mengcopy meme tidak selalu sempurna, karena sangat sulit untuk menceritakan kembali lelucon dengan kata-kata yang sama dan tepat dimana kata tersebut diucapkan. Shifman juga menyebutkan bahwa meme merupakan unit imitasi. Atas hal tersebut dia mencoba membagi beberapa dimensi meme yang berpotensi diimitasi oleh orangorang, diantaranya:

1. Content, yaitu mengacu pada ide dan ideologi yang tergabung dalam teks (misalnya tema dan framingnya).

2. Form, yaitu berkaitan dengan bentuk. Selain itu juga merupakan inkarnasi fisik dari pesan yang dapat dirasakan melalui indra. Hal ini mencakup dimensi visual / suara yang spesifik untuk teks tertentu, serta pola yang berkaitan dengan genre yang lebih kompleks yang mengaturnya (seperti lipsynch atau animasi). Form juga bisa dilihat melalui kualitas produksi, seperti amatir, profesional dan semi profesional.

3. Stance,yaknidimensiyang berhubungan dengan komunikasi. Stance digunakan untuk menggambarkan bagaimana para pengunggah memposisikan diri mereka dalam teks (sudut pandang). Pada dimensi stance, Shifman memecahnya lagi ke dalam tiga subdimensi, yakni (1) participation structures, menggambarkan siapa yang berpartisipasi atau terlibat dalam teks, (2) keying, berhubungan dengan nada dan gaya komunikasi, dan (3) communicative functions, berhubungan dengan 6 dasar fungsi komunikasi manusia.

Gal dkk. (2015) mendefinisikan meme internet sebagai kelompok item digital dengan membagikan karakteristik umum dari konten, bentuk, dan sikap yang dibuat dengan kesadaran penuh, lalu diedarkan, ditiru dan diubahan melalui internet oleh banyak pengguna. Gambar budaya populer dan pesan ringkas turut digunakan dalam meme internet agar menciptakan pesan yang lucu (Bellar, 2013). Meme biasanya diambil dari kejadian yang menarik, bisa dari kesalahan pengejaan, sesuatu yang unik, dan kejadian lucu. Meme dapat disebarkan melalui berbagai media, melalui social network, news platform, milis, dan blog. Meme Internet membawa properti tambahan yang tidak ada pada meme biasa, karena disebarkan melalui internet, meme internet meninggalkan jejak yang dapat dilacak dan dapat dianalisis (Coscia, 2013).

Penelitian meme di media baru sudah beberapa kali dilakukan, salah satunya dilakukan oleh Juditha Christyani (2015) dengan judul "Meme di Media Sosial: Analisis Semiotik Meme Haji Lulung". Penelitian ini ingin mengetahui makna yang terdapat dibalik simbol-simbol meme \#Savehajilulung. Metode yang digunakan yakni analisis semiotik dengan pendekatan kualitatif. Sebagai analisisnya, peneliti mengunakan analisis semiotik dari Charles Pierce yang menekankan pada tanda, obyek, dan penafsir. Penelitian ini menggunakan purposive sampling. Hasil penelitian ini menyimpulkan bahwa meme Haji Lulung yang beredar di Twitter dimaknai sebagai sindiran dan ketidaksukaan kreator meme terhadap Haji Lulung. Selan itu, meme tersebut mampu membuat netizen untuk bersatu menyidir Haji Lulung, hal tersebut karena tokoh Haji Lulung merupakan politikus yang pantas tidak disukai.

Penelitian yang juga membahas meme selanjutnya diteliti oleh Noam Gal, Limor Shifman, dan Zohar Kampf (2015) berjudul "It Gets Better: Internet Memes and the Construction of Collective Identity". Penelitian ini menggunakan dua metode, yaitu analisis konten kuantitatif dan analisis kritis kualitatif berdasarkan pendekatan narasi. Tekning sampling yang digunakan yakni purposive sampling. Hasil penelitian ini yaitu video $/ t$ Gets Better dianggap sebagai kampanye. Meme secara persuasif digunakan untuk 
mengajak masyarakat agar tidak membully orang yang berorientasi Lesbian, Gay, Be sexual, Transgender (LGBT). Selain itu, meme juga digunakan untuk membangun identitas dan norma kolektif.

Dari kedua penelitian di atas, penelitian yang dilakukan saat ini lebih cenderung pada penelitian Limor Shifman yang berjudul It Gets Better: Internet Memes and the Construction of Collective Identity. Penelitian ini juga akan menggunakan analisis isi dengan teori digital meme sebagai teknik analisis datanya. Namun yang membedakan dengan penelitian terdahulu yakni terletak pada fokus yang dibahas. Dimana penelitian ini membahas meme politik Setya Novanto akan kasus korupsi e-KTP 2017 yang menjadi viral di dunia maya.

Di Indonesia, penelitian mengenai analisis isi dengan teori digital meme masih belum banyak dilakukan. Hal tersebut yang membuat penelitian ini penting dan layak untuk diteliti. Berdasarkan latar belakang di atas, diperoleh rumusan masalah, "Bagaimana konstruksi pesan meme internet Setya Novanto di Youtube berdasakan model analisis content, stance, dan form?"

\section{B. METODE}

Penelitian ini menggunakan jenis penelitian deskriptif kualitatif, yakni penelitian yang bertujuan untuk mendiskripsikan secara sistematis, faktual dan akurat mengenai objek tertentu. Penelitian deskriptif bertujuan untuk mengembangkan konsep dan menghimpun fakta-fakta, bukan menguji hipotesis (Bajari, 2015: 45). Sedangkan penelitian kualitatif digunakan untuk menemukan atau mengembangkan teori yang sudah ada, (Pujileksono, 2015: 35).

Terdapat dua teknik pengumpulan data dalam penelitian ini, yakni data primer dan data sekunder. Data primer diperoleh dari pengumpulan data berupa video meme internet Setya Novanto yang beredar di Youtube. Sementara data sekunder diperoleh dari berbagai kajian dan literatur yang berhubungan dengan permasalahan yang dibahas seperti dari buku teks, media massa dan internet.

Populasi dalam penelitian ini adalah video meme Setya Novanto yang beredar di Youtube pada Oktober 2017 hingga Desember 2017. Peneliti menggunakan purposive sampling untuk mengambil sampel yang diperlukan. Purposive sampling yakni sampel yang ditentukan berdasarkan ciri-ciri khusus yang sesuai dengan tujuan penelitian. Adapun prosedur pengambilan sampel sebagai berikut:

1. Menggunakan kata kunci "The Power of Setya Novanto" untuk mengumpulkan meme video Setya Novanto di Youtube. Peneliti menggunakan kata kunci tersebut berdasakan beredarnya tagar \#ThePowerofSetyaNovanto yang menjadi trending topic dan dibagikan hampir 15.000 kali (bbc, 2017).

2. Setelah melakukan pencarian dengan kata kunci, kemudian dilakukan pemfilteran berdasarkan relevansi waktu, yakni terbatas pada 3 bulan pertama setelah menangnya Setya Novanto dari sidang praperadilan pada 29 September 2017.

3. Setelah itu, peneliti melakukan pemfilteran video secara manual dan ditemukan 52 meme video Setya Novanto. Pemfilteran video secara manual dilakukan karena tidak semua video yang ditemukan sesuai dengan keinginan peneliti. Video yang tidak memuat unsur meme akan direduksi.

4. Dari 52 meme video yang ditemukan, peneliti memilih lagi meme video yang hanya memuat satu tema di dalamnya.

5. Setelah difilter kembali, tersisa 27 meme video yang memuat satu tema dalam satu video. Dari 27 video tersebut terdapat 3 tema besar di dalamnya, diantaranya:

6. kesaktian Setnov (10 video), kecelakaan (7 video), dan sidamg perdana (3 video). Sedangkan 7 video sisanya bertemakan Setnov ketiduran, sakit, wawancara Aiman, dan satu kata untuk Setnov. 
7. Dari beberapa tema di atas peneliti memilih 3 tema besar untuk dijadikan sampel, dimana setiap tema akan diambil masing-masing satu video. Ketiga tema ini diantaranya kesaktian, kecelakaan, dan sidang perdana Setya Novanto.

Teknik analisis data yang digunakan adalah analisis isi kualitatif. Pada dasarnya analisis isi kualitatif memandang bahwa segala produksi pesan adalah teks, seperti sinetron, berita, iklan, lagu, dan simbolsimbolyang tidakbisalepas darikepentingan sang pembuat pesan (Kriyantono, 2006: 252). Peneliti menggunakan analisis isi dengan mengikuti model analisis meme Loar Shifman, yakni dengan memecah setiap video menjadi tiga dimensi: Content (konten), stance (sudut pandang), dan form (bentuk).

Ukuran kualitas sebuah riset terletak pada kaabsahan data atau validitas data yang dikumpulkan selama riset. Pada penelitian ini, peneliti menggunakan triangulasi sumber sebagai validitas data. Menurut Kriyanto (2006), triangulasi sumber digunakan untuk membandingkan atau mengecek ulang derajat kepercayaan informasi yang diperoleh dari sumber yang berbeda. Misalnya bisa membandingkan apa yang dikatakan umum dengan yang dikatakan pribadi, bisa menggunakan dokumen tertulis, catatan tulisan pribadi, gambar atau foto yang dapat memberikan pandangan berbeda tentang fenomena yang diteliti.

\section{HASIL DAN PEMBAHASAN}

Data yang dibahas dalam penelitian ini akan dibagi dalam 3 tema. Ketiga tema tersebut diantaranya: kesaktian Setya Novanto, kecelakaan menabrak tiang listrik, dan sidang perdana Setya Novanto. Setiap tema akan dibagi dalam 2 bagian, bagian pertama menjelaskan mengenai original text, atau teks asli yang diimitasi oleh pembuat meme. Sedangkan bagian 2 berisi mengenai unpacking meme yang berisi analisa tiga dimensi meme (content, form, stance).

\section{Kesaktian Setya Novanto}

\section{a. \#ThePowerofSetyaNovanto}

Tema kesaktian Setya Novanto diawali dengan adanya berita mengenai bebasnya Setya Novanto dari status tersangka korupsi e-KTP. Status tersangka yang disandangnya digugurkan oleh hakim Cepi Iskandar pada 29 September 2017. Dikutip dari Tribunnews.com, bahwa menururt Cepi Iskandar penetapan status tersangka pada Setya Novanto tidak sah dan tidak sesuai prosedur (Waskita, 2017). Saat itu Setya Novanto ditetapkan sebagai tersangka dengan tuduhan menyalahgunakan kewenangan hingga mengakibatkan negara mengalami kerugian sebesar $\operatorname{Rp} 2,3$ triliun (Aliansyah, 2017).

Lolosnya Setya Novanto dalam kasus hukum bukanlah kali pertama bagi dirinya. Sebelumnya, mantan ketua DPR $\mathrm{RI}$ ini juga pernah lolos dari enam kasus hukum lain. Licinnya Setya Novanto dari jeratan hukum membuatnya dijuluki "Papa yang Sakti" oleh warganet. Banyak masyarakat yang kesal terhadap kekuatan Setya Novanto yang lagilagi bisa lepas dari jeratan hukum. Kekesalan masyarakat ini kemudian dituangkan dalam bentuk sindiran bertagar \#ThePowerofSetyaNovanto. Tagar tersebut kemudian menjadi viral dan trending topic di Twitter (bbc, 2017). 


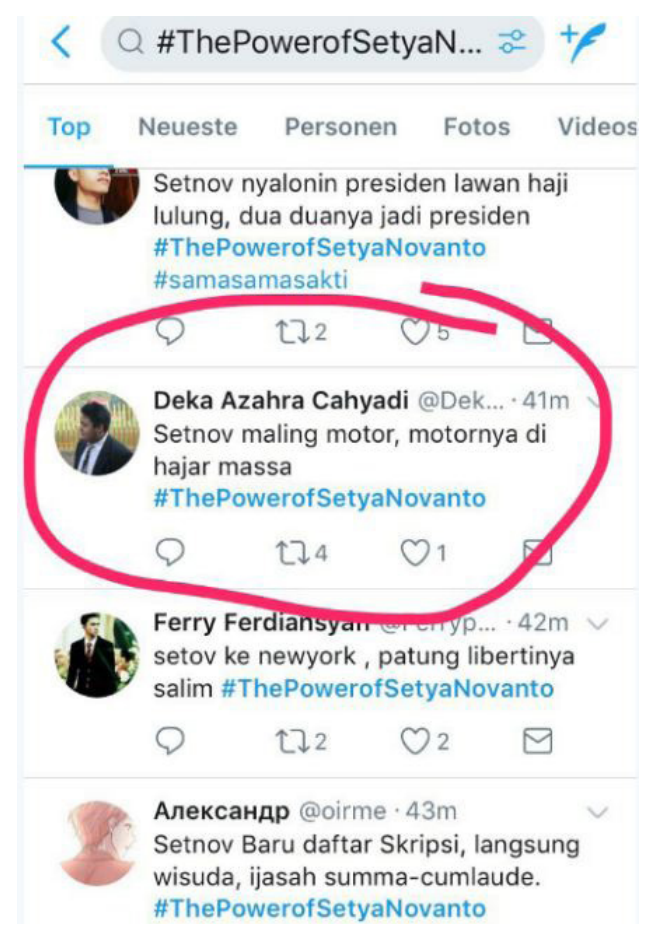

Gambar 5

Alwan Fadhal @alwanfadhal·1 Oct 2017

Setnov AFK pas maen mobile legends, yang di banned musuh nya

\#ThePowerofSetyaNovanto

(6) Translate Tweet

Q 1 โป 1 O

Danny Primadipta@dprima_sby.1 Oct 2017

Setyanovanto lewat kuburan, setannya yang baca ayat kursi

\#ThePowerofSetyaNovanto

(2) Translate Tweet

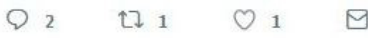

randy arya @oi_randy · 1 Oct 2017

\#ThePowerofSetyaNovanto SN sliding tackle, wasit yang kena kartu merah

6. Translate Tweet

Q $น$

ใ] $O_{1} \quad \square$

Gambar 6

Gambar 5 merupakan cuitan warganet yang dimuat dalam media elektronik bbc.com. Sedangkan gambar 6 merupakan cuitan warganet yang peniliti ambil dari Twitter. Twitt bertagar \#ThePowerofSetyaNovanto tersebut dikemas dalam guyonan satir dan dikaitkan dengan berbagai hal, dari maling motor hingga setan baca ayat kursi. Ide sindiran yang terdapat dalam tagar tersebut berisi mengenai Setya Novanto merupakan sosok kuat dan tidak tertandingi.

Tagar \#ThePowerofSetyaNovanto yang beredar di Twitter rata-rata menggunakan fungsi bahasa emotif. Roman Jakobson (dalam Rahayu, 2014) menjelaskan bahwa fungsi emotif bahasa digunakan untuk mengungkapkan perasaan (ekspresi diri). Sehingga fungsi emotif yang terdapat pada tagar di atas digunakan warganet untuk mengekspresikan rasa kesalnya pada Setya Novanto yang lolos dalam sidang pra peradilan. Sedangkan gaya komunikasi yang digunakan tagar di atas adalah ironi. Warganet yang menggunakan tagar tersebut memposisikan diri mereka sebagai masyarakat biasa yang kesal terhadap Setya Novanto. Tagar \#ThePowerofSetyaNovanto ini beredar dalam bentuk cuitan (teks) di Twitter.

\section{b. Unpacking meme video The Power of Setnov}

1) Content

Parodi berjudul "The Power of Setnov" ini berdurasi satu menit. Parodi ini diambil dari potongan scene film Downfall tahun 2004. Downfall merupakan film asal Jerman yang terinspirasi dari Tokoh Adolf Hitler. Adolf Hitler merupakan seorang pemimpin besar rezim Nazi Jerman tahun 19341945. Dalam kemimpinannya, Hitler bertanggungjawab atas pembunuhan 11 juta orang, termasuk pembunuhan 6 juta orang bangsa Yahudi (Yasinta, 2018).

Video parodi "The Power of Setnov" menceritakan mengenai Setya Novanto yang memiliki kekuatan super dan tidak tertandingi. Scene film Downfall yang dijadikan parodi The Power of Setya Novanto yaitu scene ketika Hitler sedang marah besar di dalam bunker. Parodi ini menggunakan karakter Hitler untuk menganalogikan kekuatan Setya Novanto. Terdapat 49 pemain di dalamnya, diantaranya terdapat satu tokoh utama yang berperan sebagai komandan (Adolf Hitler), tiga orang sebagai pemeran pembantu (para jenderal), dan yang lainnya sebagai figuran yang mendukung jalannya 
cerita. Video ini memuat sindiran kesaktian Setya Novanto yang dibingkai dalam verball bullying. Bagian awal video digambarkan beberapa tentara sedang melaporkan sebuah berita kepada Hitler. Berita tersebut mengenai bebasnya Setya Novanto dari status tersangka korupsi dan julukan "Papa yang sakti" yang disematkan kepadanya. Mendengar berita tersebut, Hitler pun marah sambil berkata "Dia udah merugikan negara 2,3 triliun, ini pasti ada sesuatu yang gak bener disini". Selain mengatakan kalimat tersebut, Hitler dan salah seorang jenderal juga mengatakan sindiran satir yang ditujukan kepada Setnov.

Jenderal : "Dia (Setya Novanto) sakti karena dia suka makan micin banyak-banyak, tapi yang jadi bego micinnya"

Hitler : "Dan yang gua tau kesaktian Setia Novanto itu pas dia sekolah dapat nilai rapot merah semua, yang gak naik itu gurunya"

Sindiran di atas mengisyaratkan bahwa Setya Novanto merupakan sosok yang kuat. Bahkan hal apapun tidak dapat menandingi kekuatan Setya Novanto.

\section{Batara Jogiandra S @batarajogi}

Setnov kesandung batu, batunya yang minta maaf \#ThePowerofSetyaNovanto

(1) Translate Tweet

10:23 PM - 30 Sep 2017

10 Retweets 23 Likes

Q โป $10 \quad \bigcirc 23 \quad \square$

Gambar 7

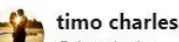

timo charles @timocharles

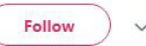

Setnov mantannya nikah,mantannya yg galau. \#ThePowerOfSetyaNovanto

\section{- Translate Tweet}

12:36 PM - 30 Sep 2017

26 Retweets 38 Likes

○ $\quad$ ᄂ $26 \quad \bigcirc 38 \quad \boxminus$

Gambar 8
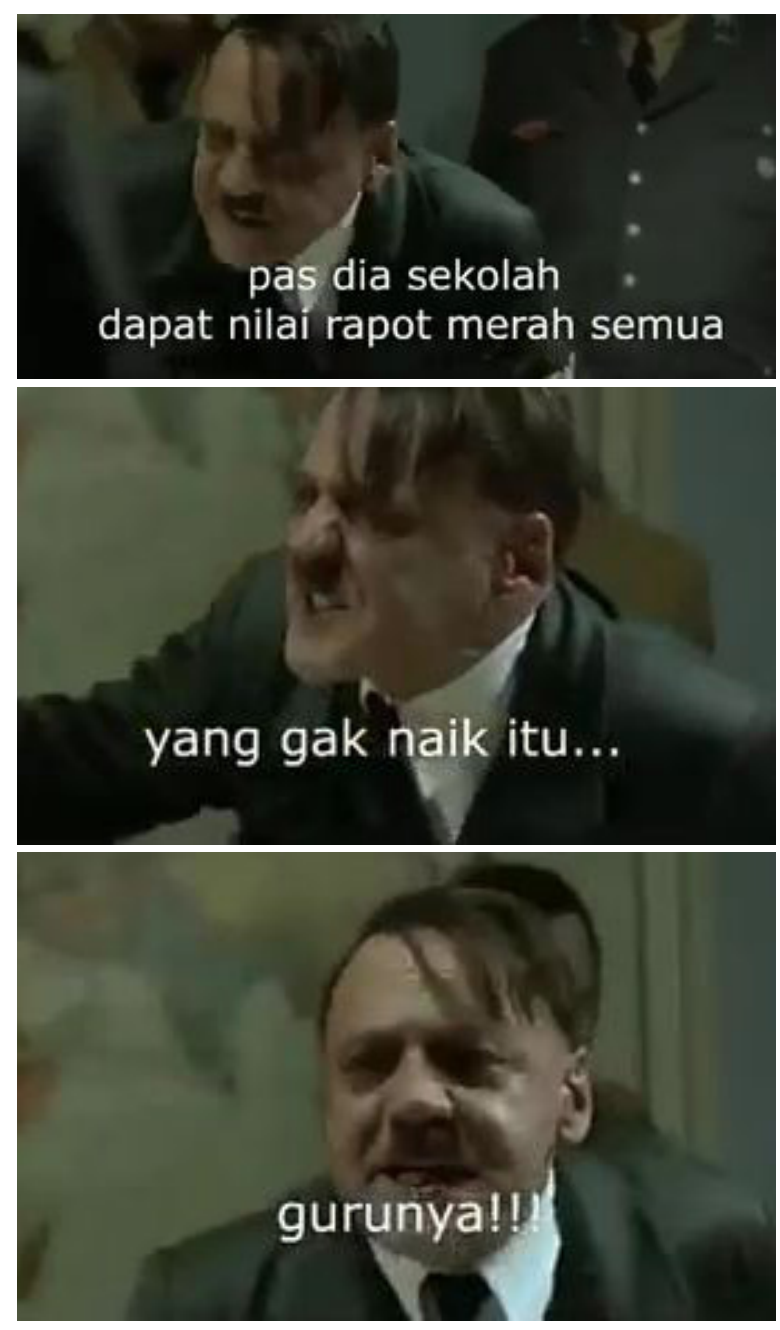

Gambar 9
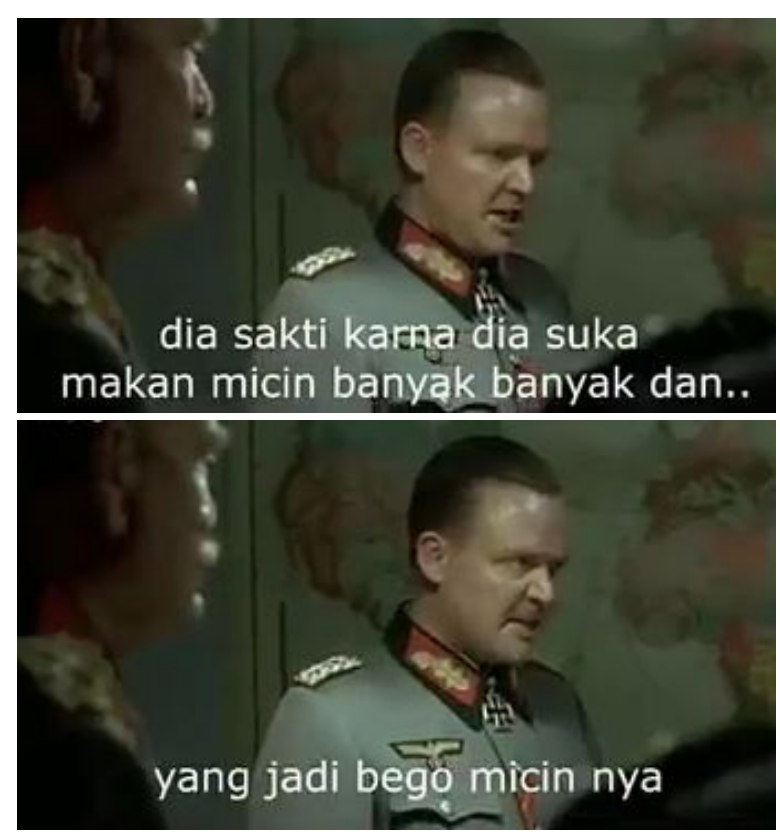

Gambar 10 
Video parodi di atas terinspirasi dari viralnya tagar \#ThePowerofSetyaNovanto di Twitter. $\mathrm{Hal}$ tersebut dibuktikan dengan adanya sindiran satir yang ditujukan pada Setya Novanto. Gambar 7 dan 8 merupakan sindiran bertagar \#ThePowerofSetyaNovanto yang beredar di Twitter. Sedangkan gambar 9 dan 10 merupakan sindiran yang diucapkan Hitler dan salah seorang jenderal di video parodi "The Power of Setnov". Konsep sindiran yang disajikan video parodi di atas mirip dengan konsep sindiran yang terdapat dalam tagar \#ThePowerofSetyaNovanto. Dimana ide sindiran yang diterdapat dalam keduanya sama-sama merujuk pada Setya Novanto yang memiliki kekuatan super dan tidak tertandingi.

Video parodi di atas juga mengadopsi beberapa hal mengenai kasus korupsi e-KTP Setya Novanto yang dimuat dalam berita online. Hal tersebut bisa dilihat dari dialog sang komandan yang menyebut "kerugian negara mencapai 2,3 triliun". Dimana penyebutan kerugian 2,3 triliun tersebut sesuai dengan realitas yang dimuat dalam pemberitaan di media elektronik, salah satunya pada berita berjudul "Berkali-kali Lolos Hukum, Setya Novanto Terjerat di Kasus e-KTP" yang dimuat dalam Merdeka.com.

Kreator video parodi "The Power of Setnov" menganalogikan kekuatan Setya Novanto dengan penggunaan tokoh Adolf Hitler. Adolf Hitler terkenal dengan sosok yang kuat dan kejam. Namun dalam parodi tersebut, Setya Novanto justru disajikan sebagai sosok yang mampu menandingi kekuatan dan kesaktian Hitler. Hal tersebut dibuktikan dengan dialog Hitler yang marah dan berat hati harus mengakui betapa saktinya Setya Novanto.

2) Form

Video parodi yang diambil dari potongan scene film Downfall di atas tetap mempertahankan dialog berbahasa Jerman dengan dilengkapi subtitle berbahasa Indonesia. Setting tempat yang digunakan yakni ketika Hitler sedang marah besar di dalam bunker. Para pemain mengenakan seragam nazi Jerman era 1945.

Kualitas produksi pada video ini sudah tergolong profesional. Karena Downfall merupakan film Hollywood maka sinematrografinya sudah sangat diperhatikan. Audio yang digunakan dapat membangun emosi penonton. Tata pencahayaan, dan angle pengambilan gambar ditata dengan begitu baik. Selain itu, video ini juga terlihat menggunakan video editing profesional.

Form dari video parodi ini berbeda dengan original teksnya. Original teksnya berbentuk tagar \#ThePowerofSetyaNovanto, sedangkan meme di atas berbentukvideo. Sehingga dimensi form yang terdapat dalam original teks tidak ada yang diimitasi oleh meme The Power of Setnov.

\section{3) Stance}

Video The Power of Setnov diambil dari potongan scene film Downfall, film Downfall diproduksi oleh Jerman dan dibintangi beberapa pemain Eropa. Sehingga tokoh yang terdapat pada video The Power of Setnov adalah orangorang Eropa berkulit putih dengan ras Arya. Ras Arya merupakan Ras yang dianggap superior (paling bagus). Pemain dalam video ini diperankan oleh 38 laki-laki dan 1 perempuan dengan kategori muda dan tua.

Menurut Shifman (2013), dimensi stance berhubungan dengan nada dan gaya komunikasi yang dibentuk oleh partisipan mereka. Blum et al. dalam (Shifman, 2013) menjelaskan, setiap orang dapat memasukkan gaya komunikasi mereka secara serius, lucu, ironis, berpura-pura, dan mengejek. Dalam kasus The Power of Setnov, tokoh utama Hitler menggunakan komunikasi ironi dengan nada bicara yang penuh emosional. Dirinya juga menggunakan 
kata-kata kasar dan mengeluarkan sindiran satir. Sedangkan fungsi bahasa yang digunakan dalam video ini adalah fungsi emotif. Fungsi emotif ini digunakan untuk mengungkapkan perasaan kesal dan marah yang ditujukan pada Setya Novanto. Gambar 11, 12 dan 13 di bawah merupakan fungsi emotif yang didukung dengan ekspresi marah Hitler. Posisi pengalamat dalam video parodi ini yakni, seorang diktator yang tidak terima atas bebasnya Setya Novanto dari status tersangka korupsi e-KTP.

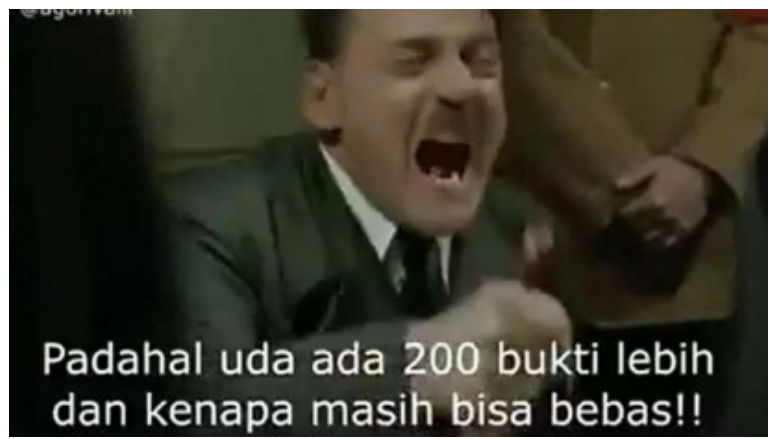

Gambar 11

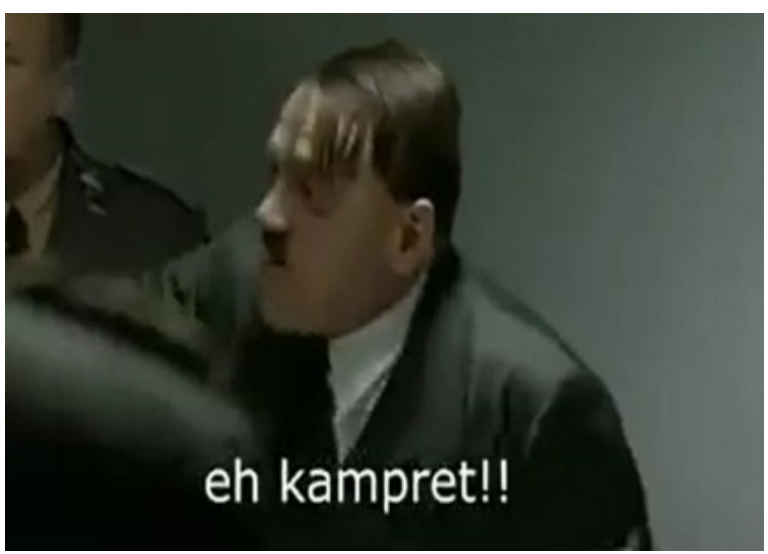

Gambar 12

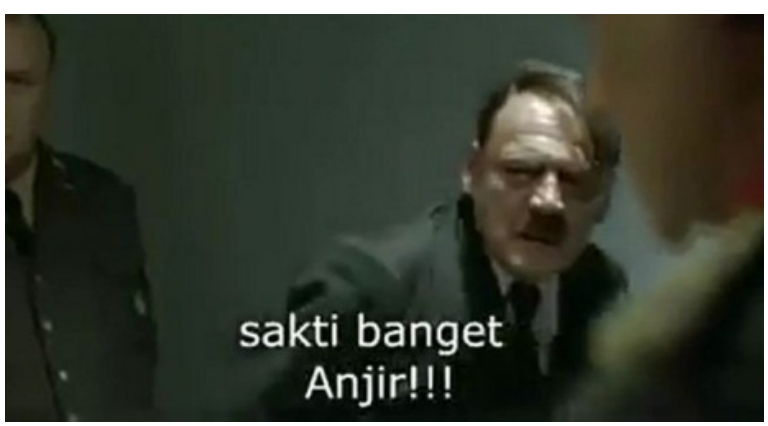

Gambar 13
Terdapat kesamaan fungsi bahasa yang digunakan teks asli dengan video parodi "The Power of Setnov". Mereka sama-sama menggunakan fungsi bahasa emotif yang digunakan untuk mengungkapkan rasa kesal pada Setya Novanto. Namun perbedaannya, parodi "The Power of Setnov" lebih memilih menggunakan beberapa kata kasar untuk mengungkapkan rasa kesalnya, sedangkan cuitan dengan tagar \#ThepowerofSetyaNovanto hanya menggunakan kata-kata satir tanpa ada kata kasar.

Sementara itu terdapat perbedaan pada posisi pengalamat yang digunakan. Teks asli memposisikan mereka sebagai masyarakat biasa yang peduli akan kasus korupsi. Sedangkan posisi pengalamat video parodi "The Power of Setnov" adalah seorang diktator yang tidak terima dengan bebasnya Setya Novanto dari status tersangka korupsi e-KTP.

\section{Kecelakaan menabrak tiang listrik}

\section{a. \#Savetianglistrik}

Tema kecelakaan menabrak tiang listrik diawali dengan adanya berita mengenai kecelakaan Setya Novanto pada 16 November 2017. Mobil fortuner yang ditumpanginya mengalami kecelakaan tunggal menabrak tiang listrik di kawasan Jakarta Selatan. Dikutip dari Cnnindonesia.com, bahwa saat kecelakaan Novanto sedang bersama ajudannya dan salah seorang wartawan lepas (Taylor, 2017). Penyebab kecelakaan diduga karena pengemudi kurang berkonsentrasi saat mengemudikan mobil. Kurangnya konsentrasi pengemudi mobil diakibatkan dirinya sedang menerima telepon, mengobrol dengan Setya Novanto, dan dalam keadaan lelah saat mengemudikan mobil (Ratnasari, 2017).

Berbagai kejanggalan bermunculan ketika hanya Novanto saja yang mengalami luka-luka dan tak sadarkan 
diri, sedangkan ajudan dan wartawan yang berada dalam satu mobil dengannya dalam keadaan baik-baik saja. Merespon hal tersebut, warganet justru memberikan reaksi lucu. Warganet yang kesal dengan "drama" Seya Novanto kemudian membuat postingan berbau lelucon dengan tagar \#savetianglistrik. Tagar \#savetianglistrik ramai diperbincangkan warganet dan berhasil menjadi tranding topic di Twitter. Kicauan warganet tersebut kebanyakan bernada sarkas yang menyayangkan adanya kecelakaan. Banyak pula twitt warganet yang seolaholah menganggap tiang listrik adalah manusia. Dalam twitnya, warganet menganggap tiang listrik sebagai manusia dengan cara mendoakannya, memberinya semangat, menjadikan tiang listrik sebagai korban maupun tersangka, dan mengaitkannya dengan kejadian lain. Gambar 14 dan 15 merupakan cuitan bertagar \#Savetianglistrik yang beredar di Twitter, cuitan tersebut seakan menganggap tiang listrik adalah manusia.

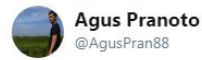

Info penting!!!

PLN besok akan memadamkan listrik secara bergantian di seluruh wilayah indonesia dari jam 9.00 s/d 13.00,jam 15.00 s/d 21.00,jam $22.00 \mathrm{~s} / \mathrm{d} 24.00$.

Karena besok semua tiang listrik akan ke Jakarta membesuk temannya yg di tabrak.. हो 100 धी

\#SaveTiangListrik

\section{Gambar 14}

Ardhanta $^{\mathrm{Tu}} @$ @sDeyz.16 Nov 2017

Replying to @KompasTV

Polisi belum bisa mintai keterangan korban, krn korban (tiang listrik) sedang dlm penanganan dokter di RS Medika PH

\#SaveTiangListrik

(1) Translate Tweet

$\begin{array}{llllll}2 & 24 & 0 & 22 & \square\end{array}$

Gambar 15

\footnotetext{
Tagar \#Savetianglistrik yang beredar di Twitter rata-rata menggunakan fungsi bahasa emotif. Fungsi emotif ini digunakan warganet
}

untuk mengekspresikan rasa kasihan pada tiang listrik dan rasa kesal pada Setya Novanto. Gaya komunikasi yang digunakan yakni berpura-pura. Warganet berpura-pura simpati dengan tiang listrik, namun niat utamanya adalah menyindir Setya Novanto. Warganet yang menggunakan tagar tersebut memposisikan diri mereka sebagai masyarakat yang kesal atas "drama" yang dilakukan Setya Novanto agar terbebas dari jerat hukum. Tagar \#Savetianglistrik ini beredar dalam bentuk cuitan (teks) di Twitter.

\section{b. Unpacking meme video Setya vs Tiang Listrik}

1) Content

Video berjudul "Setya Novanto VS Tiang Listrik" ini berdurasi 3 menit 23 detik. Terdapat 4 orang pemain di dalamnya, dalam setiap scene para pemain berganti peran dan karakter. Video parodi tersebut menceritakan mengenai kecelakaan Setya Novanto dan kisah tiang listrik yang dianggap sebagai makhluk hidup.

Video parodi "Setya Novanto VS Tiang Listrik" dibagi menjadi dua bagian, bagian pertama menceritakan Setya Novanto menabrak tiang listrik dan bagian kedua mengisahkan tiang listrik yang dianggap sebagai makhluk hidup. Pada awal video dibuka dengan adegan Setya Novanto menerima telepon saat sedang mengendarai sepeda motor. Berkendara sambil menelepon membuat Setya Novanto kehilangan kendali dan berujung pada kecelakaan menabrak tiang listrik. Merasa tidak terima dan menjadi korban kecelakan, Setya Novanto dibantu warga setempat justru memukuli tiang listrik yang ditabraknya. Bagian kedua video ini diceritakan bahwa tiang listrik yang dianggap sebagai makhluk hidup sudah menjadi bagian dalam drama kehidupan manusia, seperti: tiang listrik dijadikan teman untuk berfoto, bermain game, ngobrol, dan menjadi saksi dalam kisah cinta anak muda. 
Bagian pertama video parodi di atas berusaha meniru kecelakaan yang menimpa Setya Novanto pada 16 November 2017. Berita yang dilansir Cnnindonesia.com menyebut, bahwa kecelakaan tunggal Setya Novanto salah satunya diakibatkan sopir yang tidak fokus lantaran menerima telepon (Ratnasari, 2017). Kejadian tersebut kemudian diimitasi oleh video parodi ini dengan adegan tokoh utama menabrak tiang listrik saat menerima telepon.

Bagian kedua video parodi di atas terinspirasi dari tagar \#Savetianglistrik. Ide yang disampaikan pun juga mengikuti ide dari cuitan bertagar \#Savetianglistrik. Dimana ide yang terdapat dalam keduanya samasama merujuk pada tiang listrik yang dianggap sebagai makhluk hidup (manusia).

Cuitan bertagar \#Savetianglistrik menganggap tiang listrik sebagai manusia dengan cara mendoakan, memberinya semangat, dan menganggapnya sebagai korban atau tersangka dalam kecelakaan Setya Novanto. Sedangkan video parodi ini menganggap tiang listrik sebagai manusia dengan cara mengajaknya berinteraksi. Hal tersebut dibuktikan dalam adegan tiang listrik yang diajak bermain game, membicarakan masalah e-KTP, dihormati layaknya manusia, dan menjadi saksi dalam kisah cinta anak muda.

\section{2) Form}

Video "Setya Novanto VS Tiang listrik" mengambil lokasi pengambilan gambar di kawasan perumahan. Pengambilan gambar di kawasan perumahan di dukung dengan adanya satpam, aktifitas warga yang sedang mengobrol, dan adanya tiang listrik yang menjadi objek utama dalam video ini. Video parodi ini menggunakan properti sepeda motor dan handphone sebagai penyebab kecelakaan Setya Novanto. Wardrobe yang dikenakan pemain terkesan santai dan seadanya.
Mereka hanya mengenakan celana jeans dengan atasan kaos dan kemeja.

Kualitas produksi video "The Power of Setnov" yaitu semi profesional. Video tersebut sudah memperhatikan aspek sinematografi (sound, lighting, angle), namun masih terdapat kekurangan dan belum sempurna. Pada scene Setya Novanto sedang menerima telepon, terlihat jelas scene tersebut menghasilkan gambar yang shaking. Walaupun berlokasi di outdor, suara pemain bisa terdengar jelas. Namun sayangnya audio yang digunakan untuk membangun mood penonton bukanlah audio yang original (kreator mengambil dari internet). Video ini sudah memainkan beberapa angle pengambilan gambar, namun masih terkesan sederhana.

Form dari video parodi ini berbeda dengan original teksnya. Original teksnya berbentuk tagar \#Savetianglistrik, sedangkan meme video di atas berbentuk video. Sehingga dimensi form yang terdapat dalam original teks tidak ada yang diimitasi oleh meme The Power of Setnov.

\section{3) Stance}

Pemain pada video parodi "Setya Novanto VS Tiang Listrik" ini adalah orang Indonesia berkulit sawo matang. Para pemainnya berasal dari etnis betawi, hal ini diketahui dari penggunaan aksen dan dialek betawi ketika berdialog. Video ini diperankan oleh empat orang pemuda, diantaranya tiga orang laki-laki dan satu orang perempuan beragama islam. Tiga orang laki-lali tersebut tidak ditunjukkan berafiliasi dengan agama tertentu, sedangkan satu orang perempuan dianggap beragama islam karena menggunakan jilbab yang merupakan identitas perempuan muslim (beragama islam).

Pada video ini, para pemain menggunakan gaya komunikasi yang lucu. Fungsi bahasa yang digunakan yaitu fungsi fatik. Menurut Hamid Hasan Lubis (1993), fatik yaitu fungsi 
bahasa yang digunakan sebagai pengantar pembicaraan atau biasa disebut basa-basi. Sedangkan fungsi fatik dalam video ini digunakan untuk menjalin komunikasi dan mengadakan kontak dengan orang lain maupun tiang listrik. Fungsi fatik yang terdapat dalam video parodi ini diantaranya, "permisi", "hei mbak", "hei tiang listrik". Posisi pengalamat pada video ini yakni sebagai warga betawi yang berteman dengan tiang listrik.

Dimensi stance pada video parodi ini tidak ada yang mengikuti teks aslinya. Video parodi tidak mengikuti fungsi bahasa yang digunakan karena konten yang disajikan sudah berbeda. Teks asli menggunakan fungsi emotif karena kontennya adalah mengungkapkan suatu perasaan. Sedangkan video parodi ini menggunakan fungsi fatik karena berfokus untuk mengadakan kontak dengan tiang listrik maupun lawan main.

Perbedaan juga terdapat pada posisi pengalamat yang digunakan. Teks asli memposisikan diri mereka sebagai masyarakat yang kesal akan drama yang dilakukan Setya Novanto. Sedangkan video parodi "Setya Novanto VS Tiang Listrik" memposisikan diri mereka sebagai warga yang berteman dengan tiang listrik.

\section{Sidang perdana Setya Novanto}

\section{a. Breaking News Metro TV}

Program berita Breaking News Metro TV yang diunggah ke Youtube telah dilihat sebanyak 391.147 viewers. Video tersebut berdurasi 12 menit. Video ini menayangkan Sidang perdana Setya Novanto yang diwarnai drama panjang. Sidang yang dilaksanakan pada 13 Desember 2017 tersebut beragendakan pembacaan surat dakwaan terhadap Setya Novanto. Terdapat peristiwa menarik yang terjadi dalam sidang perdana tersangka korupsi e-KTP Setya Novanto, diantaranya:
1) Setya Novanto yang selalu diam dan menduduk saat ditanya hakim

Saat hakim membuka sidang, beberapa pertanyaan diajukan kepada Setya Novanto,"Apakah nama lengkap saudara setya novanto?", Setya Novanto hanya diam dan menunduk, setelah beberapa saat dirinya izin ke kamar mandi. Hakim pun mengulangi pertanyaannya lagi, "apakah nama lengkap saudara Setya Novanto?" Setnov pun tidak menjawab dan justru mengatakan bahwa dirinya sedang diare. Kemudian hakim kembali bertanya kepada Setnov, "tempat lahir Bandung?" dengan pelan dia menjawab "Jawa Timur". Namun ketika hakim kembali menanyakan alamat, agama, dan pekerjaan Setnov, dia kembali terdiam dan tidak menjawab sepatah katapun. Melihat respon Setya Novanto yang selalu diam, hakim pun memilih untuk menskors persidangan.

2) Jaksa menyebut bahwa Setya Novanto berpura-pura sakit

Beberapakali tidak merespon pertanyaan hakim, Setya Novanto mengaku bahwa dirinya sedang sakit diare. Mendengar pernyataan tersebut, Jaksa Putri Irene meyakinkan hakim bahwa Setya Novanto dalam keadaan baik. Putri Irene pun menilai bahwa Setya Novanto berbohong dengan berpura-pura sakit. Dokter ahli yang dihadirkan dalam persidangan pun juga menyebut bahwa Setya Novanto dalam kondisi yang sehat.

Dalam suasana persidangan, tentu gaya komunikasi yang digunakan adalah gaya komunikasi yang serius. Ketika persidangan berlangsung, hakim berusaha menghimbau Setya Novanto untuk menjawab pertanyaan yang diajukan dan sempat meminta peserta sidang untuk tidak gaduh. Kedua hal tersebut menunjukkan bahwa fungsi bahasa yang digunakan adalah fungsi konatif. Roman Jakobson (dalam Rahayu, 2014) menjelaskan bahwa fungsi konatif digunakan sebagai 
pengungkap keinginan pembicara untuk segera dilakukan oleh sang penyimak. Sedangkan sudut pandang yang terdapat pada program berita Breaking News Metro TV yaitu netral, berita tersebut hanya menayangkan siaran langsung sidang perdana Setya Novanto.

\section{b. Unpacking meme video Parodi Supiano Panto}

1) Content

Video berjudul "Parody Supiano Panto" menceritakan tingkah dan kebohongan Supiano Panto saat sidang berlangsung. Video berdurasi 5 menit 41 detik ini menyebutkan bahwa Supiano Panto merupakan tersangka maling ayam. Selayaknya persidangan pada umumnya, parodi ini juga menyajikan berbagai pertanyaan hakim kepada terdakwanya. Berbagai pertanyaan yang diajukan hakim diantaranya, siapakah nama lengkap saudara, apakah agama dari saudara, apakah saudara benar terlibat dalam kasus ini, dan apakah peran anda dalam kasus ini.

Pada persidangannya, tersangka Supiano Panto digambarkan sebagai sosok yang pandai mengelabuhi. Hal tersebut dibuktikan dengan aksi Supiano Panto yang selalu bungkam dan "berpura-berpura sakit" saat hakim menanyakan identitas padanya. Kepurapuran Supiano Panto tersebut antara lain, berpura-pura tidak mendengar, lapar, sakit kepala, dan terkena serangan jantung. Ketika Supiano Panto berpurapura sakit, dokter pun memeriksa dirinya dan memastikan bahwa Supiano Panto dalam keaadaan baik.Video parodi ini ditutup dengan suasana sidang yang gaduh akibat aksi lucu dukun yang mampu mengobati Supiano Panto dari serangan jantung.

Video "Parody Supiano Panto" di atas mengimitasi ide yang terdapat pada teks asli (Sidang Setya Novanto, Breaking News Metro TV). Parodi tersebut menampilkan berbagai kejadian yang terdapat pada teks asli dengan mengemasnya menjadi lebih lucu dan mendramatisir. Nama Supiano Panto yang terdapat dalam video parodi merupakan pelesetan dari nama Setya Novanto. Sedangkan kasus korupsi e-KTP dipelesetkan menjadi kasus maling ayam.

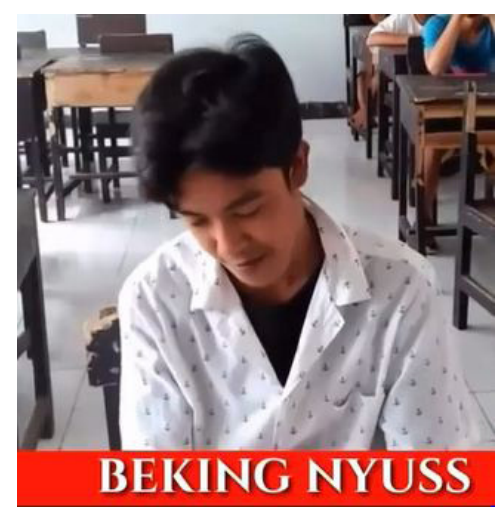

Gambar 16

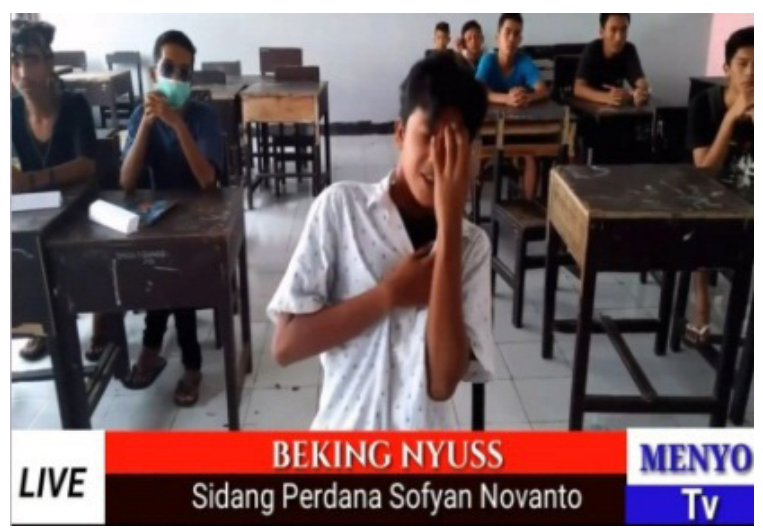

Gambar 17

Gambar 16 merupakan adegan Sofyan Novanto yang bungkam dan menunduk ketika hakim melontarkan pertanyaan padanya. Bungkam dan menunduknya Sofyan Novanto tersebut mengimitasi dari sikap Setya Novanto di sidang perdananya. Berbagai pertanyaan hakim yang juga diikuti oleh video parodi ini adalah, "apakah nama anda Supiano Panto?", "Apakah agama dari saudara?", dan "Tempat lahir Bandung?". Sedangkan gambar 17 merupakan adegan Sofyan Novanto yang berpura-pura mendapat serangan jantung. Ide berpura-pura sakit dan mendapat serangan jantung merupakan hasil meniru dari Setya Novanto yang mengaku sakit diare di 
sidang perdananya. Adanya dokter ahli yang turut dihadirkan dalam parodi persidangan semakin menguatkan bahwa video parodi ini mengimitasi sidang perdana Setya Novanto yang disiarkan di Breaking News Metro TV.

\section{2) Form}

Tampilan video ini dibuat seperti berita televisi, dimana terdapat nama channel televisi dan CG (Character Generic) di bagian bawah. Video tersebutmengambil lokasipengambilan gambar di ruang kelas. Ruang kelas tersebut dirubah layaknya ruang persidangan. Sedangkan wardrobe yang digunakan pemain sudah lumayan terkonsep. Masing-masing pemain mengenakan baju dan atribut yang disesuikan dengan provesi dan tokoh yang diperankannya.

Kualitas produksi video "Parodi Supiano Panto" yaitu semi profesional. Video tersebut sudah memperhatikan aspek sinematografi (sound, lighting, angle), namun masih terdapat kekurangan dan belum sempurna. Video ini minim lighting, mereka hanya memanfaatkan sinar matahari untuk penggarapan video. Hal tersebut mengakibatkan beberapa scene ada yang terlihat terang dan ada yang terlihat gelap. Video ini berusaha memberikan kesan lucu dengan menambahkan beberapa audio tambahan yang didapat di internet. Pengambilan angle video ini masih tergolong sederhana. Selain itu juga terdapat ketidaktelitian dalam proses editing, hal ini ditinjukkan dengan adanya perbedaan penulisan "nama" antara judul yang disematkan dengan CG (Character Generic) yang dimunculkan dalam video. Dalam judul dituliskan nama "Supiano Panto", sedangkan dalam CG dituliskan "Sofyan Novanto". Perbedaan penulisan nama tokoh utama tersebut dapat membuat penonton menjadi bingung.

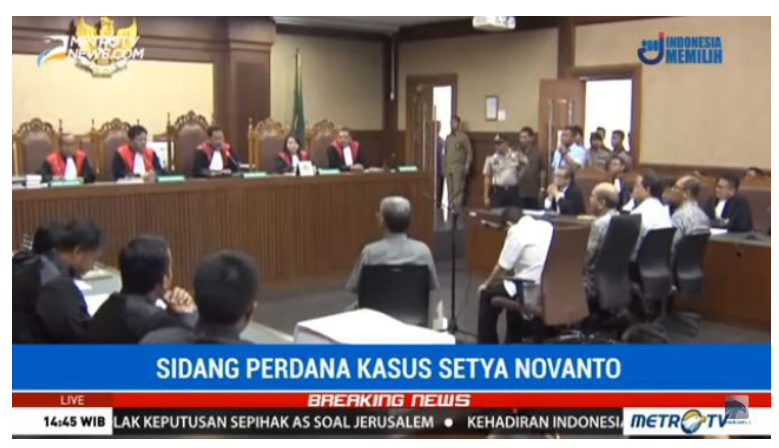

Gambar 18

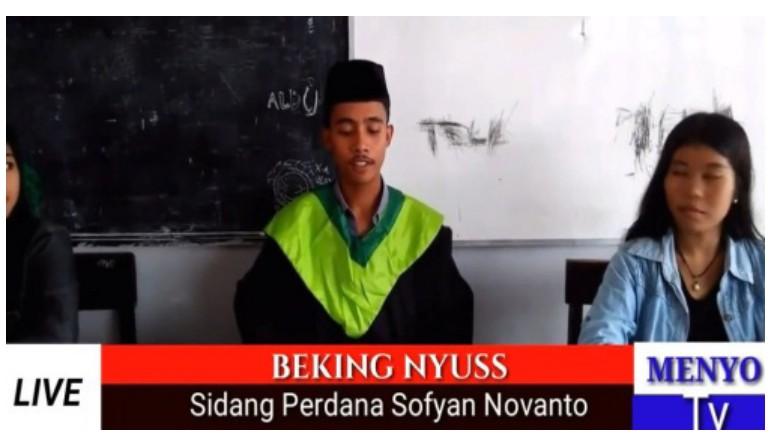

Gambar 19

Gambar 18 merupakan tampilan program berita Breaking News Metro TV, sedangkan gambar 19 merupakan tampilan "Beking Nyus Menyo TV" dalam video parodi Supiano Panto. Tampilan seperti berita yang dibuat video parodi tersebut mengimitasi tampilan program berita "Breaking News" Metro Tv. Dimana video parodi tersebut mengubah nama "Breaking News" menjadi "Beking Nyuss" dan "Metrotv" menjadi "Menyo Tv". Selain itu, dimensi form yang berusaha diimitasi oleh video parodi di atas yakni setting tempat dan wardrobe yang digunakan saat sidang perdana Setya Novanto. Video parodi tersebut menggunakan setting tempat di ruang kelas, ruang kelas ditata sedemikian rupa hingga menyerupai ruang sidang Setya Novanto. Bagian depan kelas ditata beberapa meja untuk hakim dan jajarannya, sisi kiri depan meja hakim digunakan untuk pengacara, bagian tengah ruangan digunakan untuk terdakwa dan saksi ahli, dan bagian paling belakang digunakan untuk peserta sidang. 


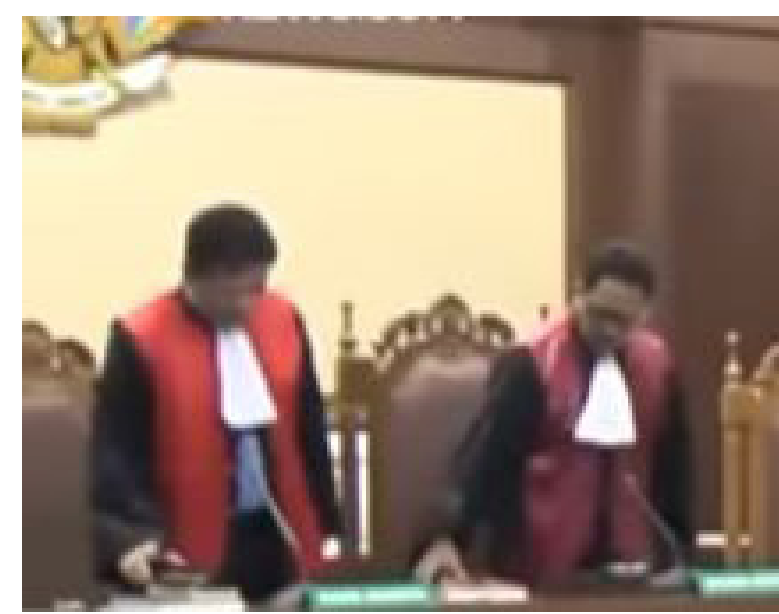

Hakim

Gambar 20

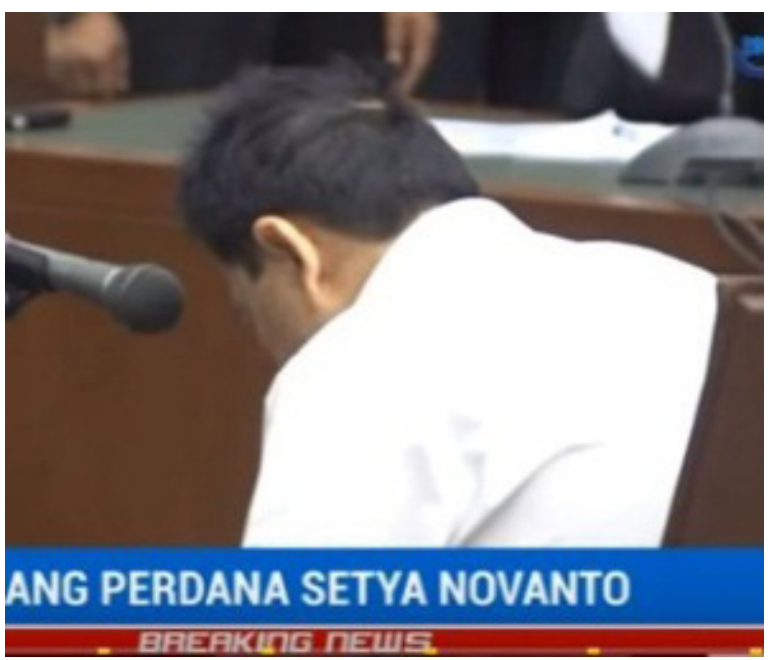

Setya Novanto

Gambar 21

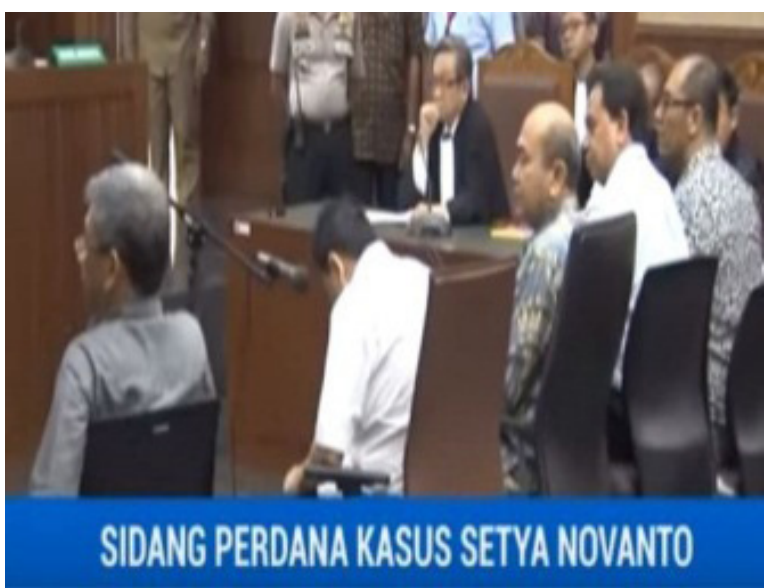

Dokter ahli

Gambar 22

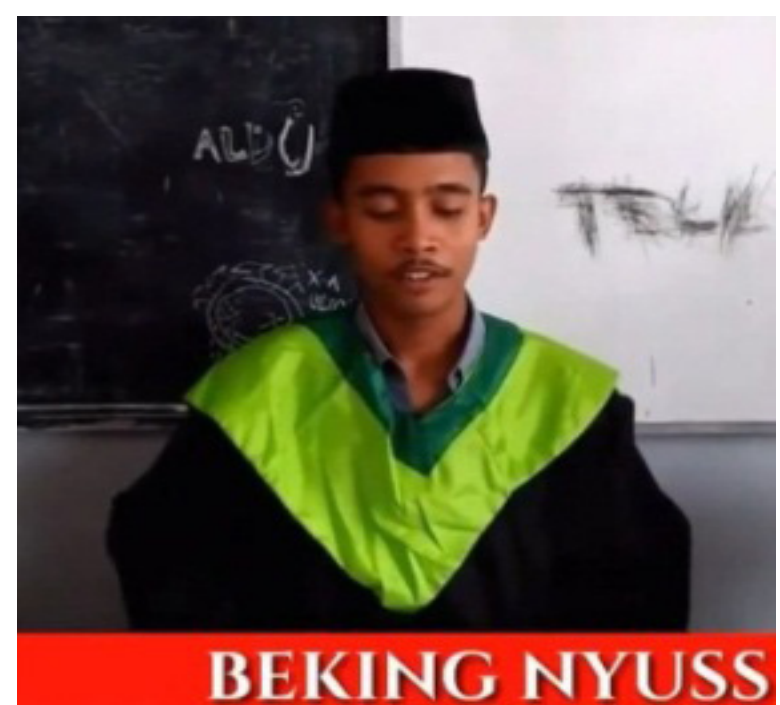

Hakim

Gambar 23

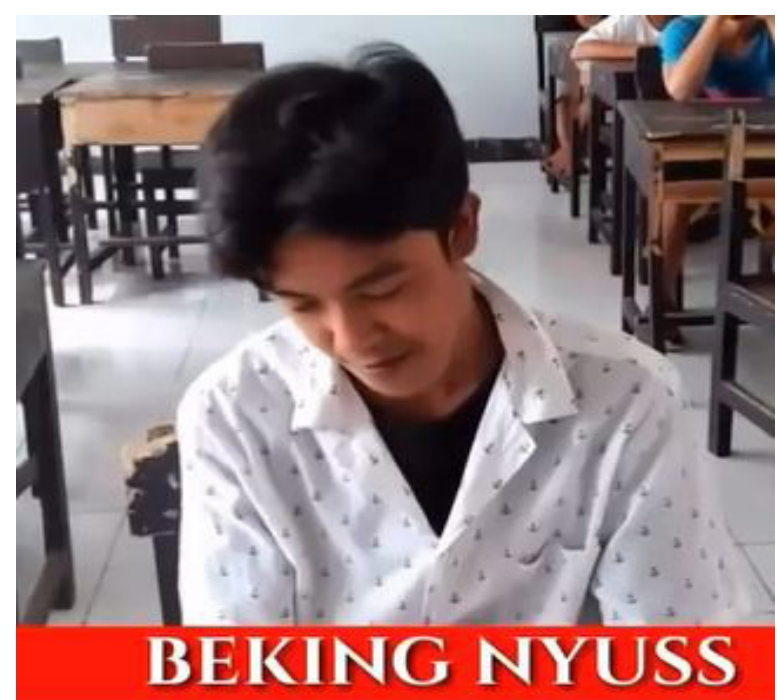

Sofyan Novanto

Gambar 24

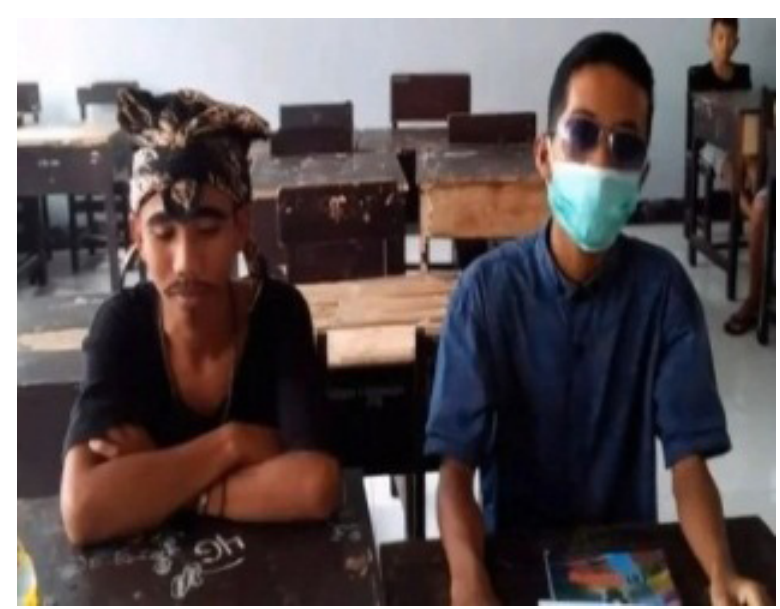

Dukun dan dokter

Gambar 25 
Gambar 20, 21, dan 22 merupakan wardrobe yang digunakan dalam sidang perdana tersangka korupsi e-KTP Setya Novanto. Sedangkan gambar 23, 24, dan 25 merupakan wardrobe yang digunakan para pemain dalam sidang tersangka maling ayam Supiano Panto. Wardrobe atau atribut yang digunakan para pemain parodi di atas meniru apa yang dikenakan oleh pihak-pihak yang terlibat dalam persidangan Setya Novanto. Atribut atau pakaian yang turut diimitasi oleh video "Parodi Supiano Panto" yakni toga yang dikenakan hakim, kemeja putih Setya Novanto, dan dokter ahli yang berpakaian rapi. Imitasi yang dilakukan video parodi tersebut tentu tidaklah sama persis. Terdapat penambahan tokoh dan atribut agar terkesan lebih lucu.

\section{3) Stance}

Pemain yang terdapat pada video Parodi Supiano Panto adalah orang Indonesia dengan warna kulit sawo matang. Video parodi diperankan oleh 11 orang remaja, diantaranya 2 orang perempuan dan 9 orang laki-laki. Sedangkan etnis dan ras dalam video ini tidak ditunjukkan secara spesifik.

Para pemain dalam video Parodi Supiano Panto menggunakan gaya komunikasi yang serius. Sedangkan fungsi bahasa yang digunakan yaitu fungsi konatif. Beberapa fungsi konatif yang ditemukan dalam video parodi ini yaitu ketika hakim terus mengingatkan agar peserta sidang tetap tenang dan ketika hakim meminta pengacara dan tim medis untuk memeriksa kondisi Setya Novanto. Posisi pengalamat pada video parodi ini yaitu sekelompok remaja yang ikut menyindir drama sakitnya Setya Novanto di sidang perdananya.

Walaupun video "Parody Persidangan Supiano Panto" dikemas secara lucu, namun video tersebut tetap mempertahankan gaya komunikasi yang serius seperti yang terdapat pada video asli. Kesan lucu video parodi ini hanya terdapat pada adegan yang diperankan, bukan dari gaya komunikasi yang disampaikan. Sedangkan fungsi bahasa yang digunakan pun juga meniru video asli, yakni fungsi konatif. Fungsi konatif ditemukan dalam kalimat yang bersifat panggilan dan perintah. Posisi pengalamat pada video ini yakni masyarakat biasa yang berusaha menyindir "drama" Setya Novanto saat sidang perdananya.

\section{PENUTUP}

Berdasarkan data yang telah dijabarkan di atas, penelitian ini menghasilkan bahwa konstruksi meme internet Setya Novanto terdiri dari tiga dimensi meme (content, form, stance). Salah satu dimensi yang banyak diimitasi oleh kreator meme dengan tingkat akurasi yang tinggi adalah dimensi content. Hampir mayoritas tema yang disampaikan oleh teks asli turut diikuti oleh penirunya. Beberapa narasi yang disajikan video peniru (meme) menekankan pada pengalaman pribadi Setya Novanto dalam kasus e-KTP. Tema utama yang diangkat teks asli dan diimitasi oleh penirunya (meme) adalah berupa sindiran terhadap kasus korupsi e-KTP Setya Novanto.

Terdapat pergantian bentuk terjadi dalam dimensi form, yakni dari teks (berita) diubah menjadi video (meme). Namun hal tersebut hanya terjadi pada meme The Power of Setnov dan Setya Novanto VS Tiang Listrik. Sedangkan pada meme Parody Supiano Panto bentuk penyeberannya tetaplah sama, yakni berupa video. Pada meme Parody Supiano Panto tersebut yang dapat diimitasi dari teks asli tidak hanya dari bentuk penyebarannya saja, namun juga dari bentuk fisik yang ditangkap oleh indera (setting dan wardrobe), dimana setting dan wardrobe yang digunakan berusaha mendekati teks aslinya. Kualitas video yang terdapat pada ketiga meme tersebut adalah semi profesional.

Pada dimensi stance, gaya komunikasi, fungsi bahasa, dan posisi pengalamat dari teks asli tidak seluruhnya ditiru oleh video penirunya (meme). Terdapat perbedaan 
sudut pandang (posisi pengalamat) yang digunakan ketiga meme diatas. Meme "Setya Novanto VS Tiang listrik" dan" Parody sidang Supiano Panto" memposisikan diri mereka sebagai masyarakat biasa. Namun meme "The Power of Setnov" lebih menggunakan sudut pandang dari sisi seorang penguasa. Sedangkan gaya komunikasi dan fungsi bahasa yang digunakan ketiga meme di atas rata-rata mengikuti teks asli. Hanya fungsi bahasa yang terdapat pada meme "Setya Novanto VS Tiang listrik" yang meyimpang dari teks aslinya. Dimana teks asli menggunakan fungsi bahasa emotif sedangkan meme "Setya Novanto VS Tiang listrik" menggunakan fungsi fatik yang digunakan untuk menjalin kontak dengan lawan bicara. Penelitian ini tentu masih terdapat kekurangan, sehingga untuk penelitian selanjutnya diharapkan mampu melengkapi dan menyempurnakan penelitian yang serupa serta dapat menggali lebih jauh mengenai model tiga dimensi meme Loar Shifman.

\section{DAFTAR PUSTAKA}

Amin, Khoirul, Mohamad D.A.A, Khusnul Khatimah. 2018. Social Media, Cyber Hate, and Racism. Jurnal Komunikasi dan Teknologi Informasi. Vol.10, No.1.

Bajari, Atwar. 2015. Metode Penelitian Komunikasi Prosedur, Tren, dan Etika. Bandung: Simbiosa Rekatama Media.

Bellar, Wendi. 2013. Reading Religion in Internet Memes. Journal of Religion, Media \& Digital Culture (JRMDC). Vol. 2, issue 2, doi: 10.1163/21659214-90000031.

Budiargo, Dian. 2015. Berkomunikasi Ala Net Generation. Jakarta: PT Elex Media.

Christiany, Juditha. 2015. Meme di Media Sosial: Analisis Semiotik Meme Haji Lulung. Jurnal Pekommas. Vol.18. No.2.

Coscia, Michele. 2013. Competition and Success in the Meme Pool: a Case Study on Quickmeme.com. International Conference of Weblogs and Social Media.

David, Eribka Ruthellia, Mariam Sondakh, Stevi Harilama. 2017. Pengaruh Konten Vlog dalam Youtube terhadap Pembentukan Sikap Mahasiswa Ilmu Komunikasi Fakultas Ilmu Sosial dan Politik Universitas Sam Ratulangi. E-journal "Acta Diurna". Vol.6. No.1.

Gal, Noam, Limor Shifman dan Zohar Kampf. 2015. It Gets Better: Internet Memes and The Construction of Collective Identity. New Media \& Society. Vol 18, issue 8, doi: $10.1177 / 1461444814568784$.

Ilham, Muhammad. 2017. Representasi Budaya Populer Meme Comic Indonesia (Analisis Semiotika Meme Dalam Fanpage Meme Comic Indonesia). Surakarta: Skripsi Universitas Hasanuddin.

Kriyantono, Rachmat. 2006. Teknis Praktis Riset Komunikasi. Jakarta: Kencana Prenada Media Group.

Lubis, Hamid Hasan. 1993. Jenggala Bahasa Indonesia. Bandung: Angkasa.

Nasrullah, Rulli. 2015. Media Sosial Perspektif Komunikasi, Budaya, dan Sosioteknologi. Bandung: Simbiosa Rekatama Media.

Pujileksono, Sugeng. 2015. Metode Penelitian Kualitatif. Malang: Kelompok Intrans Publishing.

Rahayu, Siti Perdi. 2014. Bentuk dan Fungsi Sapaan Bahasa Prancis dalam Novel Poil de Carotte Karya Jules Renard. Jurnal penelitian humaniora. Vol. 19, No.2. 
Shifman, Limor. 2012. An anatomy of a YouTube meme. New Media \& Society. Vol.14, issue 2, doi: 10.1177/1461444811412160.

Shifman, Limor. 2013. Memes in a Digital World: Reconciling with a Conceptual Troublemaker. Journal of Computer Mediated Communcation. Vol 18, issue 3.

Shifman, Limor. 2014. Meme in Digital Culture. MIT Press. Cambridge. USA

Soha, Michael, Zachary J. McDowell. 2016. Monetizing a Meme: Youtube, Content ID, and the Harlem Shake. Sage Journal. Vol. 2, issue 1, doi: 10.1177/2056305115623801.

Xu, Weiai Wayne, Ji Yong Park, Ji Young Kim, Han Woo Park. 2016. Networked Cultural Diffusion and Creation on Youtube: An Analysis of Youtube Memes. Journal of broadcasting and electronik media. Vol 60, isuue 1, DOI: 10.1080/08838151.2015.1127241.

\section{Sumber lain:}

Aliansyah, Agil Muhammad. 2017. Berkali-kali lolos hukum, Setya Novanto terjerat di kasus e-KTP. https://www.merdeka.com/peristiwa/berkali-kali-lolos-hukum-setya-novantoterjerat-di-kasus-e-ktp.html, diakses pada 18 Juli 2017.

Bbc. 2017. The Power of Setya Novanto: Satir'piawainya' Ketua DPR lepas dari jeratan hukum. https://www.bbc.com/indonesia/trensosial-41461116, diakses pada 2 Oktober 2017.

Margianto, Heru. 2016. Golkar dan Ketua Umum Baru yang Nyaris Jatuh Tertidur. https:// nasional.kompas.com/read/2016/05/18/06061961/golkar.dan.ketua.umum.baru. yang.nyaris.jatuh.tertidur, diakses pada 18 Mei 2016.

Ratnasari, Elise Dwi. 2017. Tiang Lampu Setnov Jadi Wisata baru di Jakarta Selatan. https:// www.cnnindonesia.com/gaya-hidup/20171119110118-269-256647/tiang-lampusetnov-jadi-wisata-baru-di-selatan-jakarta, diakses pada 19 November 2017.

Syahid, 2018. 6 Jenis Konten Youtube yang Dapat Ditiru untuk Meraup Untung. https:// elshinta.com/news/156206/2018/09/21/6-jenis-konten-youtube-yang-bisa-ditiruuntuk-meraup-untung, diakses pada 21 September 2018.

Taylor, Gloria Safira. 2017. Fakta dan Kejanggalan Kecelakaan Setya Novanto. https://www. cnnindonesia.com/nasional/20171117195914-12-256453/fakta-dan-kejanggalankecelakaan-setya-novanto, diakses pada 18 November 2017.

Waskita, Ferdinand. 2017. Hakim Nilai Penetapan Setya Novanto Sebagai Tersangka Tidak Sesuai Prosedur. http://www.tribunnews.com/nasional/2017/09/29/hakim-nilaipenetapan-setya-novanto-sebagai-tersangka-tidak-sesuai-prosedur?page $=2$, diakses pada 29 September 2017. 